\title{
CONTRACTILE RESPONSES OF ISOLATED RABBIT AORTAE TO TRANSMURAL STIMULATION AS AFFECTED BY CALCIUM, STRONTIUM, SODIUM AND OUABAIN
}

\author{
Noboru TODA \\ Department of Phamacology. Faculty of Medicine, Kyoto University, Sakyo-ku, \\ Kyoto, Japan \\ Received for publication November 4, 1971
}

There are a number of reports describing that not only in visceral (1-3) but also vascular smooth muscles (4-6) $\mathrm{Ca}^{++}$may be the agent linking membrane excitation to contraction. Increasing $\left[\mathrm{Ca}^{++}\right]_{0}$ may either stimulate $(7,8)$ or inhibit (9) vascular smooth muscles. Adrenaline and $\mathrm{K}^{+}$elicit contraction and an increase in the $\mathrm{Ca}^{++}$influx into smooth muscle cells $(4,10)$. Elevation of $\left[\mathrm{Ca}^{++}\right]_{i}$ depresses the first part of the contractile response of aortic muscles to adrenaline but potentiates the second part (11). Excitation of nervous elements in vascular tissues by electrical transmural stimulation results in contraction and a sharp rise in the output of noradrenaline (12). Contractile responses of isolated vessels to stimulation of periarterial sympathetic nerves are shown to relate directly to $\left[\mathrm{Ca}^{++}\right]_{0}$ ranging from 0 to $4.4 \mathrm{mM}$ (13).

It seems likely that $\mathrm{Sr}^{++}$can substitute for $\mathrm{Ca}^{++}$in the contractile mechanism of skeletal, cardiac and smooth muscles (14-18) and in the release of the neurohumoral transmitter from sympathetic nerve terminals (18). It appears that $\mathrm{Na}^{+}$acts through an antagonism to $\mathrm{Ca}^{++}$on muscular contractility $(4,19)$ and uptake of noradrenaline by sympathetic nerves (20). Ouabain is known to increase the exchangeable $\mathrm{Ca}^{++}$fraction $(21,22)$, which would be expected to participate in increased contractility.

The present study was an investigation into the effects of ions and drugs that interact with $\mathrm{Ca}^{++}$on the resting tension of the vascular smooth muscle and on its contractile response to electrical transmural stimulation and exogenous noradrenaline.

\section{METHODS}

Albino rabbits of both sexes, weighing 1.8 to $2.2 \mathrm{~kg}$, were used. Under ether anesthesia the animals were sacrificed by bleeding from both common carotid arterics. The ascending aorta was rapidly removed and cut into spiral strips. The strips were held vertically under a resting tension of $2 \mathrm{~g}$ in the muscle bath of $100 \mathrm{ml}$ capacity containing the nutrient solution. The solution was maintained at $37 \therefore 0.5 \mathrm{C}$ and gassed with a mixture of $95 \%$ ond $5 \%$ $\mathrm{CO}_{2}$. Constituents of the solution were as follows $(\mathrm{mM}): \mathrm{Na}^{+}, 162.1 ; \mathrm{K}^{+}, 5.4 ; \mathrm{Ca}^{++}, 2.2$; $\mathrm{Cl}^{-}, 157_{11} 0 ; \mathrm{HCO}_{3}{ }^{-}, 14,9 ;$ dextrose, 5.6. Osmotic adjustment was not made when $\left[\mathrm{Ca}^{++}\right]_{1}$ 
and $\left[\mathrm{Sr}^{++}\right]_{a}$ were altered. Strontium ions as $\mathrm{SrCl}_{2}$ solution were added directly to the bathing medium in the muscle chamber. Extracellular concentrations of $\mathrm{NaCl}$ were lowered by replacing with isotonic sucrose. Before measurements were taken, preparations were allowed to equilibrate for 60 to $120 \mathrm{~min}$ in the control solution and for 20 to $30 \mathrm{~min}$ in test solutions.

The vascular strips were placed between a pair of stimulating electrodes (platinum plates, $5 \times 15 \mathrm{~mm}$ ), as described by Toda, Usui and Mori (23). The prepartions were transmurally stimulated by a train of $0.3 \mathrm{msec}-$ rectangular pulses of supramaximal intensity (about $80 \mathrm{~V}$ ) applied at frequencies of 5,20 and 100/sec. The number of the electrical pulses was kept constant (200 pulses) by changing the period of stimulation (40, 10 and 2 sec for frequencics of 5,20 and $100 / \mathrm{sec}$, respectively). Contractile response to electrical stimulation applied under these conditions is shown to result from released noradrenaline (23). Electrical stimuli were provided by an electronic stimulator (Type WSE-3R, Nihonkoden Kogyo Co.).

Contractile responses to electrical transmural stimulation and noradrenaline were recorded on a two-channel penwriter (Sanei Sokki Co.). From contractions induced by the electrical stimulation three parameters were measured: the maximum tension developed, the duration of contraction at the level of half maximum tension, which will be termed 'duration' and the time from the initiation of stimulation to the peak tension, termed 'time-to-peak'. Values of the parameters obtained from aortic preparations stimulated for $10 \mathrm{sec}$ at a frequency of $20 / \mathrm{sec}$ in control media were taken as control $(100 \%)$, and relative values of those obtained in test solutions to the respective control were presented. Noradrenaline was applied directly to the nutrient solution of the muscle bath in cumulative concentrations. The tension developed at $5 \times 10^{-5} \mathrm{M}$ noradrenaline in control media was taken as $100 \%$. After $20 \mathrm{~min}$ exposure to test solutions or after $30 \mathrm{~min}$ exposure to ouabain, transmural stimulation or noradrenaline was applied. In test solutions the preparations were stimulated repeatedly at frequencies of 5,20 and $100 / \mathrm{sec}$ at intervals of 5 to $15 \mathrm{~min}$, until steady responses were attained. The results shown in the text and figures are expressed as mean values _...standard errors of the means. Comparisons were made using Student's "t" test.

Ouabain, U.S.P. (Nutritional Biochemicals Corp.), cocaine hydrochloride and dlnoradrenaline hydrochloride were used.

\section{RESULTS}

\section{Calcium and strontium}

In spirally-cut strips of the ascending aorta electrical transmural stimulation applied for $10 \mathrm{sec}$ at a frequency of $20 / \mathrm{sec}$ caused a transient incrcase in muscle tension. Mean values of the maximum tension developed, the duration and the time-to-peak were $0.84+$. $0.05 \mathrm{~g}, 1.52=0.08 \mathrm{~min}$ and $0.48 \pm 0.03 \mathrm{~min}$, respectively $(\mathrm{N}=66)$. These parameters of the induced contraction were altered by varying stimulation frequency although the total number of stimuli was kept constant (200 pulses); the developed tension was markedly 

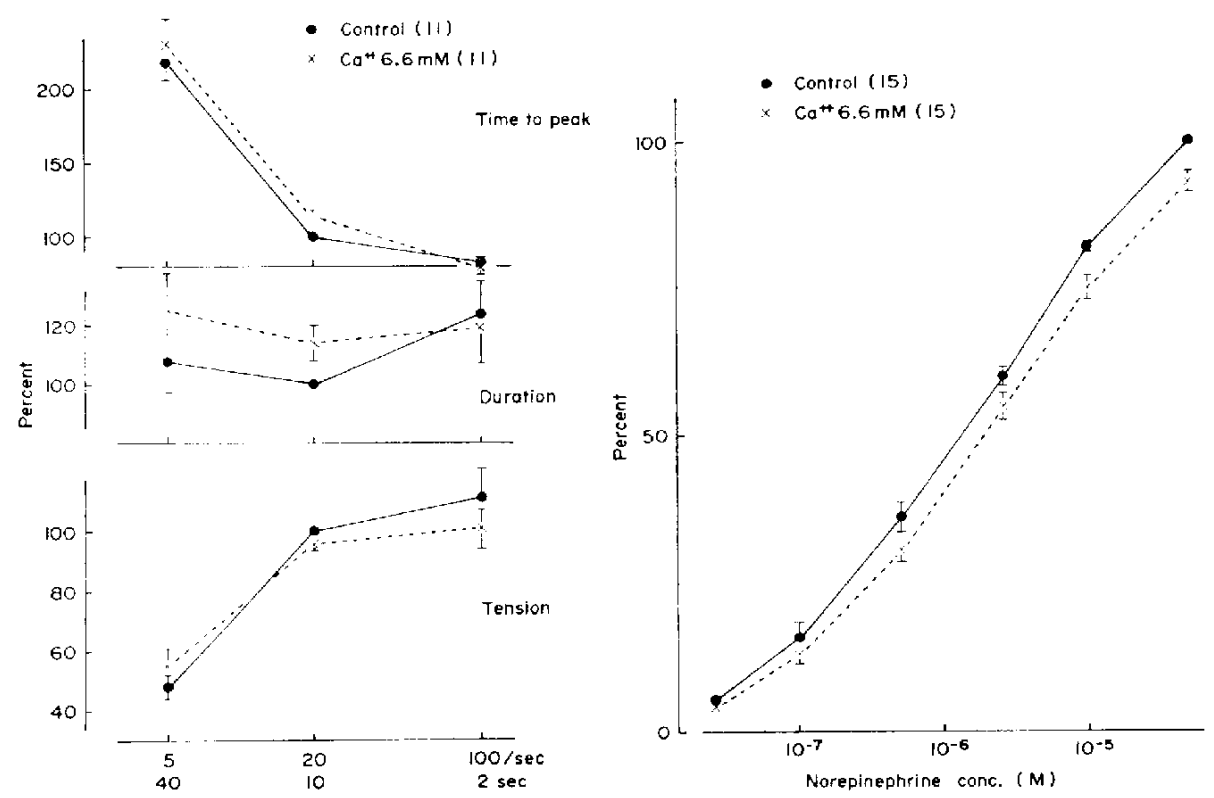

Fig. 1. Modification by elevating $\left[\mathrm{Ca}^{++}\right]_{0}$ of contractile response to transmural stimulation and noradrenaline. Left : transmural stimulation. Abscissa $=$ frequency and period of stimulation. Values of the parameters measured in individual preparations when stimulated for $10 \mathrm{sec}$ at a frequency of $20 / \mathrm{sec}$ in control media were taken as $100 \%$. Mean values of the magnitude, the duration and the time-to-peak of contraction induced under these experimental conditions were $0.79-0.13 \mathrm{~g}, 1.24 \div 0.21 \mathrm{~min}$ and $0.35 \div 0.03 \mathrm{~min}$, respectively $(\mathrm{N}=11)$. Right : noradrenaline. Values of the tension developed at $5 \times 10^{-3} \mathrm{M}$ noradrenaline in the control solution were taken as 100\% (mean value of the tension : 4,64 上 $0.34 \mathrm{~g}, \mathrm{~N}=15$ ). Figures in parentheses indicate the number of preparations.

resuced by decreasing the frequency to $5 / \mathrm{sec}$ (Fig. 1).

When the $\mathrm{Ca}^{++}$in the bathing medium was increased to $6.6 \mathrm{mM}$ (3 times normal $\left.\left[\mathrm{Ca}^{++}\right]_{0}\right)$ the tension increased slightly $(0.13 \pm 0.05 \mathrm{~g}, \mathrm{~N}: 11)$ but the contractile response to transmural stimulation was not significantly affected (Fig. 1). The dose-response curve of noradrenaline was not appreciably affected by an elevation of $\left[\mathrm{Ca}^{++}\right]_{0}$ (Fig. 1).

The addition of $\mathrm{Sr}^{++}$in concentrations of 2.2 and $4.4 \mathrm{mM}$ to contarol media did not significantly influence the magnitude and the duration of aortic contraction in response to transmural stimulation (Fig. 2). Resting tension of aortic smooth muscles was not changed by $\mathrm{Sr}^{++}$at 2.2 and $4.4 \mathrm{mM}$. Contractile response to exogenous noradrenaline was not influenced by $2.2 \mathrm{mM} \mathrm{Sr}^{++}$(Fig. 2).

Exposure of aortic preparations for 20 to $30 \mathrm{~min}$ to $\mathrm{Ca}^{++}$-free media markedly reduced the contractile response to transmural stimulation. The reduction of the response related inversely to stimulation frequency. Follwing the application of $\mathrm{Sr}^{++}$at $2.2 \mathrm{mM}$ the contractile response which had been reduced by $\mathrm{Ca}^{++}$-deficiency was partly restored in preparations stimulated at $5 / \mathrm{sec}$ and completely restored at 20 and $100 / \mathrm{sec}$. Results are summarized in Fig. 3. Resting tension which had been decreased by $0.07 \pm 0.02 \mathrm{~g}(\mathrm{~N}=12, \mathrm{P}<0.01)$ 

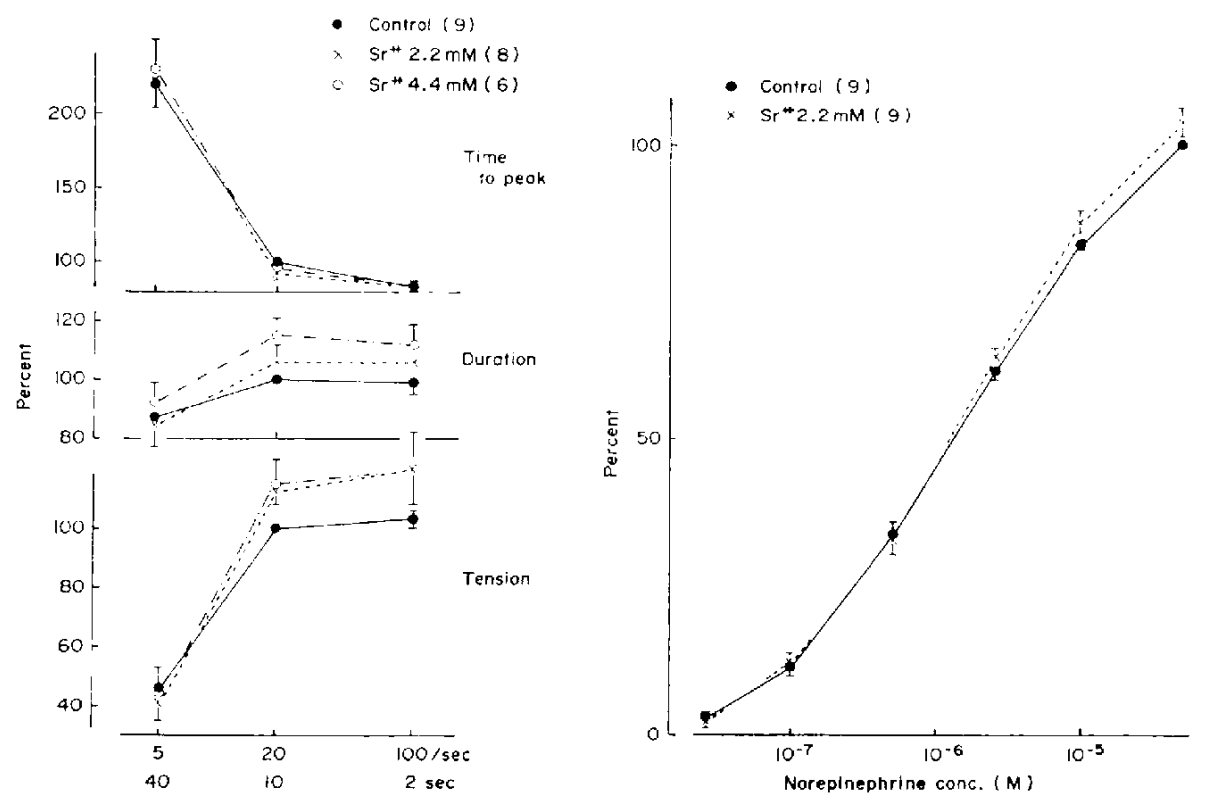

FIG. 2. Modification by $\mathrm{Sr}^{++}$of contractile response to transmural stimulation (Left) and noradrenaline (Right). Mean values of the magnitude, the duration and the time-to-peak of contraction induced by stimulation for $10 \mathrm{sec}$ at a frequency of $20 / \mathrm{sec}$ in control media were $0.80 \pm 0.12 \mathrm{~g}, 1.16 \pm 0.05 \mathrm{~min}$ and 0.34 $0.01 \mathrm{~min}$, respectivcly $(\mathrm{N}=9)$. The mean value of the tension developed at $5 \times 10^{-5} \mathrm{M}$ noradrenaline in control solution was $4.40: 0.47 \mathrm{~g}(\mathrm{~N}=9)$. Figurcs in parentheses indicate the number of preparations.

at zero $\left[\mathrm{Ca}^{++}\right]_{11}$ was restored by $2.2 \mathrm{mM} \mathrm{Sr}^{++}(0.07-:-0.02 \mathrm{~g}$ increase from the tension at zero $\left[\mathrm{Ca}^{++}\right]_{0}, \mathrm{~N}=-12$ ). Sensitivity of aortic smooth muscles to exogenous noradrenaline was reduced by removal of $\mathrm{Ca}^{++}$. Strontium ions $(2.2 \mathrm{mM})$ partly restored the sensitivity (Fig. 3).

\section{Sodium deficiency}

Decrease in the concentration of $\mathrm{Na}^{+}$in bathing media to $103.2 \mathrm{mM}$ (about $64 \%$ normal $\left.\left[\mathrm{Na}^{+}\right]_{0}\right)$ increased the resting tension of aortic strips by $0.37+\frac{1}{-1} 0.05 \mathrm{~g}(\mathrm{~N}=6)$ and potentiated significantly ( $P<0.01$, at stimulation frequencies of 20 and $100 / \mathrm{sec}$ ) the contractile response to electrical transmural stimulation. The duration was prolonged in parallel with the increased magnitude of contraction, whereas the time-to-peak was not altered (Fig. 4). The contractile response to exogenous noradrenaline in high concentrations $\left(2.5 \times 10^{-6}\right.$ and $5 \times 10^{-5} \mathrm{M}$ ) was significantly potentiated by $\mathrm{Na}^{+}$deficiency $(\mathrm{P}<0.01)$ (Fig. 4).

Further reduction of $\mathrm{Na}^{+}$in the nutrient solution to $73.8 \mathrm{mM}$ (about $45 \%$ normal $\left.\left[\mathrm{Nal}^{+}\right]_{n}\right)$ increased the resting tension by $1.14 \div 0.17 \mathrm{~g}(\mathrm{~N} \sim 10)$. The contracture developed gradually untila plateau was attained after $301060 \mathrm{~min}$ exposure to the test solution. The magnitude of contraction induced by transmural stimulation was considerably reduced by lowering $\left[\mathrm{Na}^{+}\right]_{n}$, whereas the duration was prolonged (Fig. 5). Thus, recovery from the induced contraction was markedly retarded. The time-to-peak was not appreciably affected. 

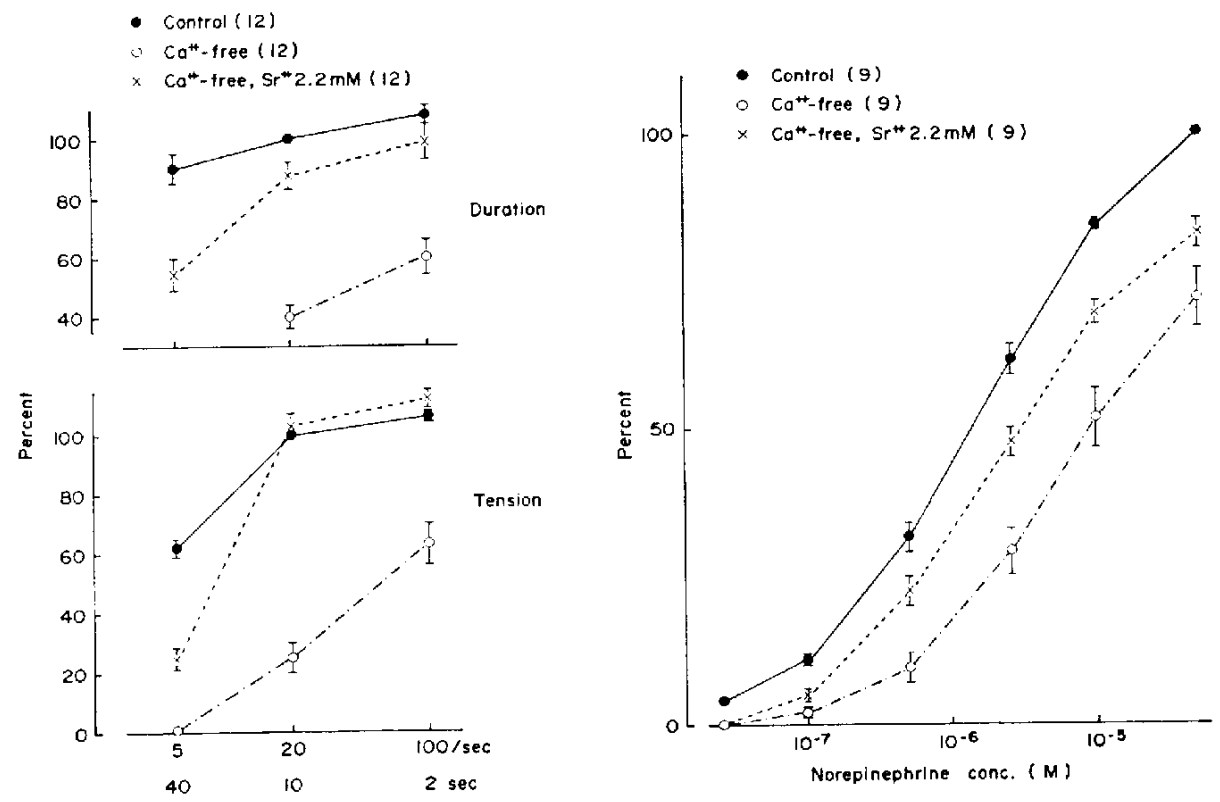

FIG. 3. Changes in contractile response to transmural stimulation (Left) and noradrenaline (Right) by renoval of $\mathrm{Ca}^{++}$and by $\mathrm{Sr}^{++}$applied in $\mathrm{Ca}^{++}$-free media. Mean values of the magnitude and the duration of contraction induced by stimulation for $10 \mathrm{sec}$ at $20 / \mathrm{sec}$ in control media were $0.65+0.07 \mathrm{~g}$ and 1.41 $\pm 0.10 \mathrm{~min}$, respectively $(\mathrm{N}=12)$. The mean value of the tension developed at $5 \times 10^{-5} \mathrm{M}$ noradrenaline in control media was $4.80 \pm 0.52 \mathrm{~g}(\mathrm{~N}=9)$. Figures in parentheses indicate the number of preparations.
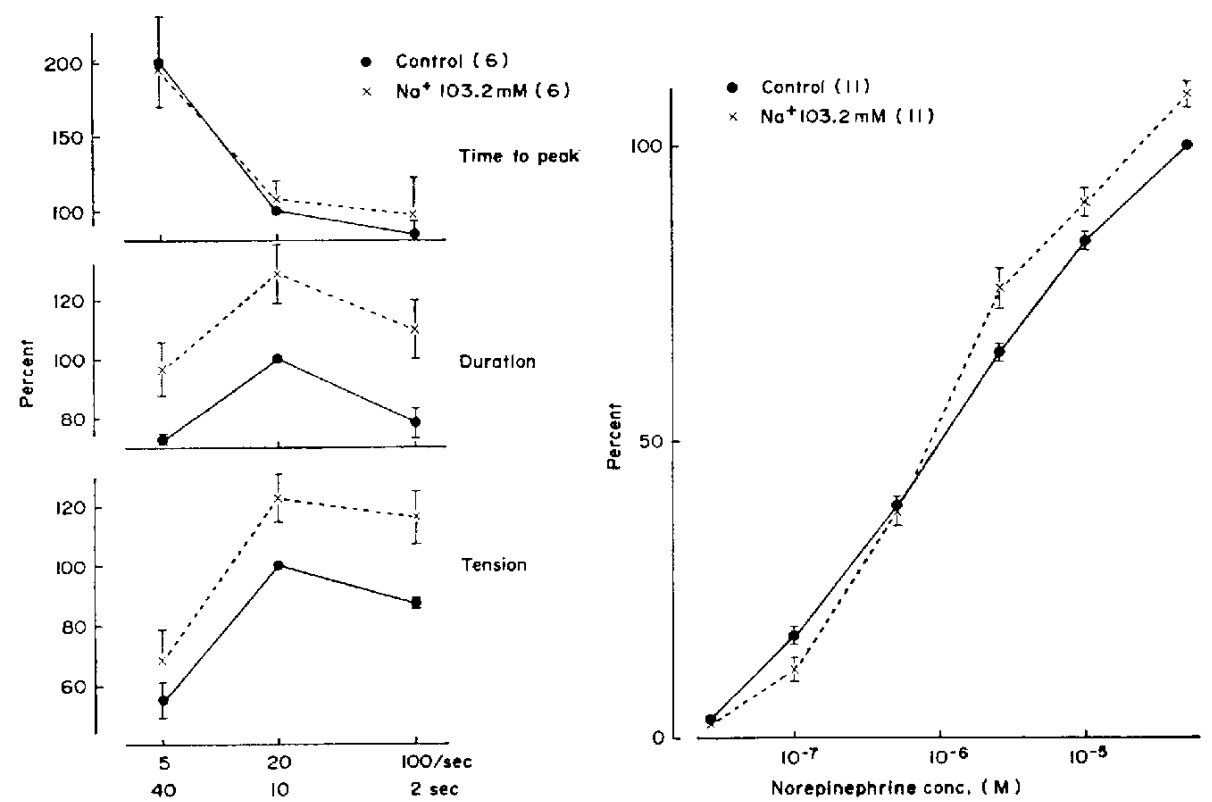

FIG. 4. Changes in contractile response to transmural stimulation (Left) and noradrenaline (Right) by lowering $\left[\mathrm{Na}^{+}\right]_{0}$ to $103.2 \mathrm{mM}$. Mean values of the magnitude, the duration and the time-to-peak of contraction caused by stimulation for $10 \mathrm{sec}$ at $20 / \mathrm{sec}$ in control media were $0.74 \pm 0.20 \mathrm{~g}, 1.81=0.21 \mathrm{~min}$ and 0.39 $\pm 0.03 \mathrm{~min}$, respectively $(\mathrm{N}=6)$. The mean value of the tension developed at $5 \times 10^{-5} \mathrm{M}$ noradrenaline in control media was $3.56 \pm 0.29 \mathrm{~g}$. 

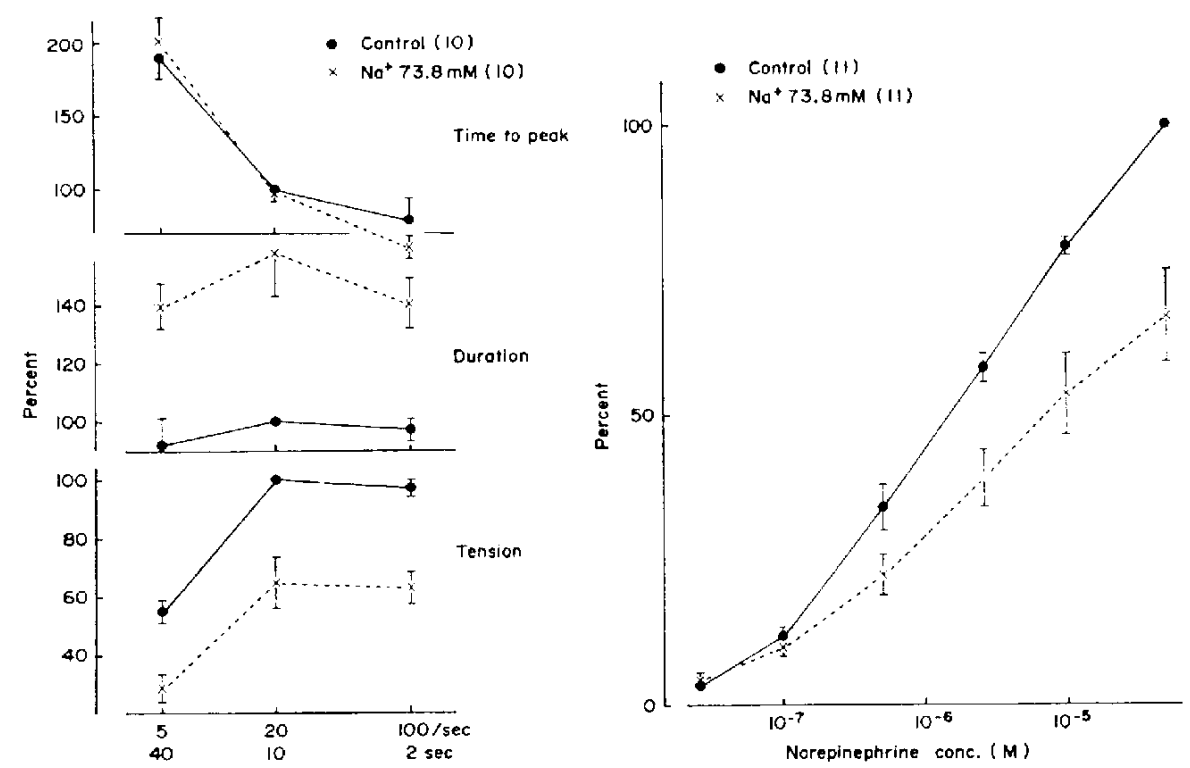

FIG. 5. Changes in contractile response to transmural stimulation (Left) and noradrenaline (Right) by lowering $\left[\mathrm{Na}^{+}\right]_{0}$ to $73.8 \mathrm{mM}$. Mean values of the magnitude, the duration and the time-to-peak of contraction induced by stimulation for $10 \mathrm{sec}$ at $20 / \mathrm{sec}$ in the control solution were $0.83 \pm 0.10 \mathrm{~g}, 1.30 \pm 0.15 \mathrm{~min}$ and $0.38 \div 0.02 \mathrm{~min}$, respectively $(\mathrm{N}-10)$. The mean value of the tension developed at $5 \times 10^{-5} \mathrm{M}$ noradrenaline in control media was $4.16 \_0.26 \mathrm{~g}(\mathrm{~N}=11)$.

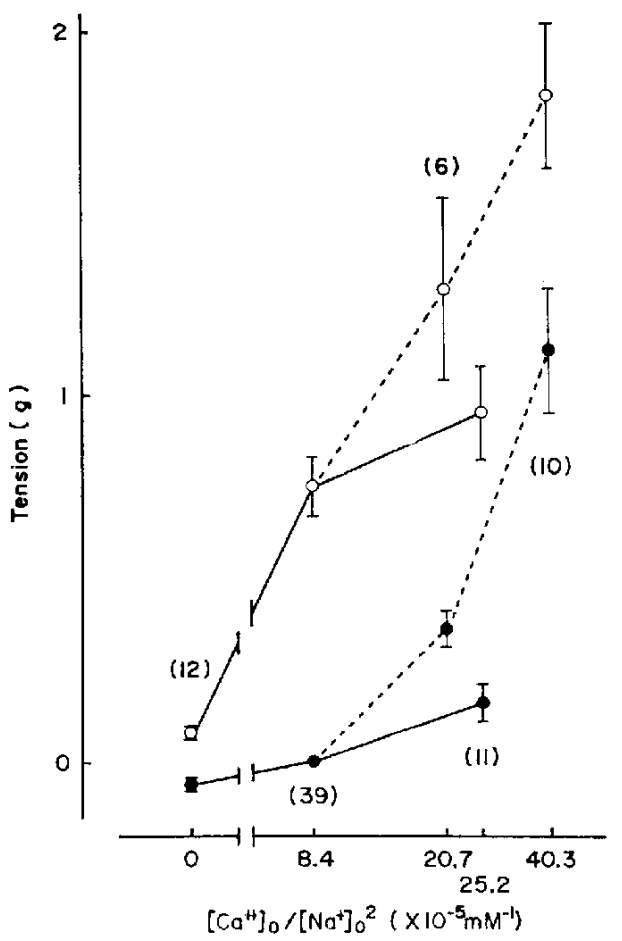

FIc. 6. Relationshin between the ratio $\left[\mathrm{Ca}^{++}\right]_{n}\left[\mathrm{Naa}^{+}\right]_{3}{ }^{2}$ and the tension developed by alteration in $\left[\mathrm{Na}^{+}\right]_{0}$ and $\left[\mathrm{Ca}^{++}\right]_{0}$ and by transmural stimulation. Filled circles - tension developed at varying $\left[\mathrm{Na}^{+}\right]_{0}$ and $\left[\left.\mathrm{Ca}^{++}\right|_{0,}\right.$. Open circles - sum of the tension developed by alterations in extracellular concentrations of the ions and by transmural stimulation at $20 / \mathrm{sec}$. Solid lines $=$ variation in $\left[\mathrm{Ca}^{++}\right]_{0}\left(\left[\mathrm{Na}^{+} l_{1}\right.\right.$ : constant $)$. Broken lines = variations in $\left[\mathrm{Na}^{+}\right]_{0}\left(\left[\mathrm{Ca}^{++}\right]_{0}\right.$ : constant). Figures in parentheses indicate the number of preparations. 
The contractile effect of exogenous noradrenaline was reduced by $\mathrm{Na}^{+}$deficiency (Fig. 5), although the resting tension in control and $\mathrm{Na}^{+}$-deficient media markedly differed (tension developed at reduced $\left[\mathrm{Na}^{+}\right]_{0}: 0.70-0.12 \mathrm{~g}, \mathrm{~N}=11$ ).

Fig. 6 demonstrates interactions of $\mathrm{Na}^{+}$and $\mathrm{Ca}^{++}$on the resting tension and the contractile response to transmural stimulation applied for $10 \mathrm{sec}$ at $20 / \mathrm{sec}$. Trends of increasing the resting tension at various $\left[\mathrm{Na}^{+}\right]_{0}$ and $\left[\mathrm{Ca}^{++}\right]_{0}$ and the sum of the tension developed by variations in $\left[\mathrm{Na}^{+}\right]_{0}$ and $\left[\mathrm{Ca}^{++}\right]_{0}$ and by transmural stimulation with increasing the ratio $\left[\mathrm{Ca}^{++}\right]_{0} /\left[\mathrm{Na}^{+}\right]_{0}{ }^{2}$ were observed. Dependence of the two parameters on reduced $\left[\mathrm{Na}^{+}\right]_{0}$ was markedly greater than that on increased $\left[\mathrm{Ca}^{++}\right]_{0}$, as far as concentrations of the ions used in this study were concerned.

\section{Ouabain}

Contractile responses of aortic strips to transmural stimulation was significantly potentiated $(\mathrm{P}<0.01)$ by ouabain in concentrations of $3.4 \times 10^{-7}$ and $3.4 \times 10^{-6} \mathrm{M}$ (Fig. 7). The duration of contraction was prolonged approximately parallel to the increase in the magnitude of contraction. The resting tension was not appreciably affected at the lower concentration but increased at the higher $(0.43\llcorner 0.09 \mathrm{~g}, \mathrm{~N}=9)$. The dose-response curve of noradrenaline was moved left by ouabain (Fig. 8). Further increase in the concentration of ouabain to

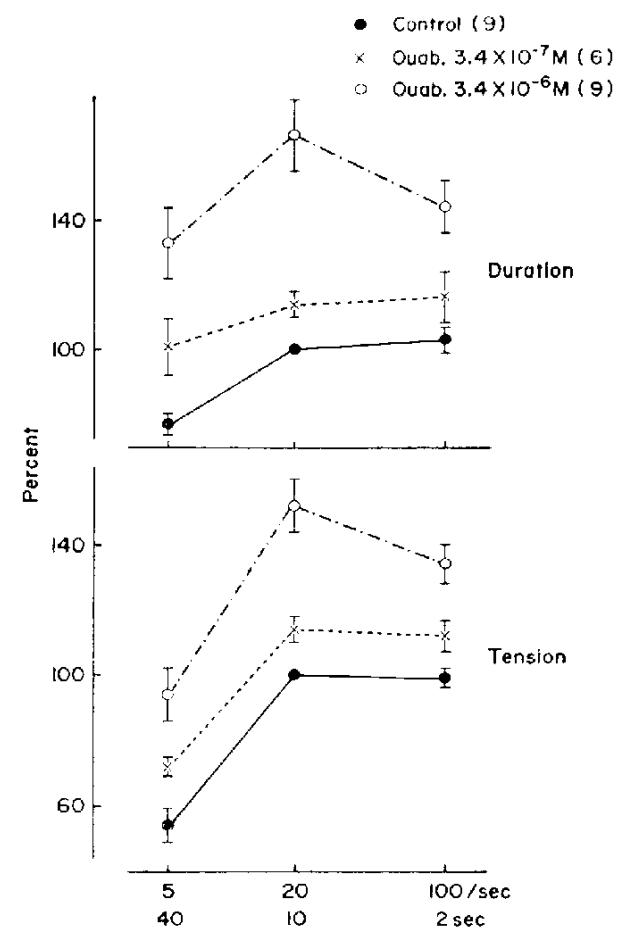

FIG. 7. Modification by ouabain of contractile response to transmural stimulation. Mean values of the magnitude and the duration of contraction induced by stimulation for $10 \mathrm{sec}$ at $20 \mathrm{sec}$ in control media were $0.95=0.15 \mathrm{~g}$ and 1.20 $0.22 \mathrm{~min}$, respeclively $(\mathbb{N}-9)$ 

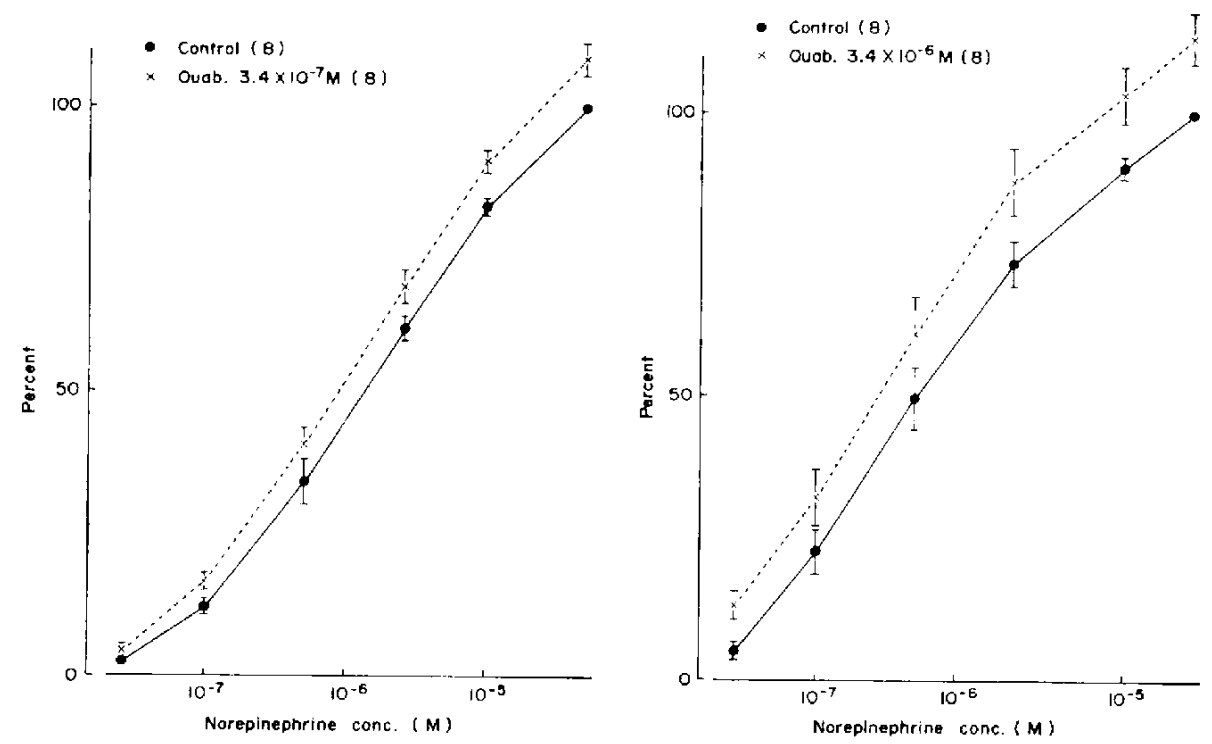

FiG. 8. Changes in the dose-response curve of noradrenaline by ouabain at $3.4 \times 10^{-7}$ (Left) and $3.4 \times 10^{-6} \mathrm{M}$ (Right). Mean values of the tension developed at $5 \times$ $10^{-5} \mathrm{M}$ noradrenaline in control media were $3.75+0.42 \mathrm{~g}(\mathrm{~N}=8$, for the Left $)$ and $4.10 \pm 0.62 \mathrm{~g}(\mathrm{~N}=8$, for the Right $)$.

$1.7 \times 10^{-5} \mathrm{M}$ caused contracture: the tension developed gradually until a plateau was attained after 60 to 120 min exposure to the glycoside $(2.24--0.38 \mathrm{~g}, \mathrm{~N}=8)$. When the contracture was completed, no contractile response to transmural stimulation was obtaincd. However, in preparations exposed for 30 to $60 \mathrm{~min}$ to ouabain in which the plateau of the contracture was not attained yet, transmural stimulation caused appreciable increase in the tension which failed to return to the level prior to stimulation. It appears that development of ouabain-induced contracture is accelerated by endogenous noradrenaline released. Repeated washing of preparations with fresh solution caused a gradual relaxation $\left(1.10 \_0.10 \mathrm{~g}\right.$, $\mathrm{N}=4$, after 90 to $120 \mathrm{~min}$ ) and a reappearance of the contractile response to transmural stimulation (the tension developed at $20 / \mathrm{sec}: 30 \pm 7.3 \%$ of the value prior to ouabain, $\mathrm{N}$ $=4$ ).

\section{Cocaine}

In 9 aortic preparations the magnitude, the duration and the time-to-peak of contraction in response to transmural stimulation at $20 / \mathrm{sec}$ averaged $0.95 \perp 0.10 \mathrm{~g}, 2.03: 0.27 \mathrm{~min}$ and $0.90 \pm 0.06 \mathrm{~min}$, respectively. Cocaine potentiated the response in a dose-dependent manner: mean values of the percent increase in these parameters by cocaine at $10^{-6} \mathrm{M}$ were $25 \perp 3.5$, $67 \pm 9.5$ and $28+4.0$, respectively $(N=8)$. The increase in the duration greatly exceeded that in the developed tension.

\section{DISCUSSION}

It has been shown that adrenaline and $\mathrm{K}^{+}$cause vascular contraction in association with 
increased flux of $\mathrm{Ca}^{++}$into smooth muscles $(4,10)$. The $\mathrm{Ca}^{++}$influx during $\mathrm{K}^{+}$-induced contracture is dependent on $\left[\mathrm{Ca}^{++}\right]_{0}$ up to $0.3 \mathrm{mM}$ and there is a linear relationship between the tension developed and the rate of entry of $\mathrm{Ca}^{++}$. Contractile response of arterial smooth muscles to adrenaline and a rise in $\left[\mathrm{K}^{+}\right]_{0}$ are promptly prevented by $\mathrm{Ca}^{++}$deionization (6). In the present study, removal of $\mathrm{Ca}^{++}$from bathing media markedly reduced the responsiveness of aortic smooth muscles to noradrenaline and electrical transmural stimulation which causes excitation of nervous elements in vascular tissues and thereby releases endogenous noradrenaline (12). Strontium ions partly restored the sensitivity to noradrenaline but completely restored the responsiveness to transmural stimulation applied at all frequencies used except for $5 / \mathrm{sec}$. Similar restoration of the response to noradrenaline, histamine and $\mathrm{K}^{+}$by $\mathrm{Sr}^{++}$applied to the $\mathrm{Ca}^{++}$-free solution has been shown in rabbit aortic strips (17). More marked restoration by $\mathrm{Sr}^{++}$of the response to sympathetic nerve stimulation than that to exogenous noradrenaline is also observed in isolated rabbit atria exposed to $\mathrm{Ca}^{++}$-free media (18). It seems likely that $\mathrm{Sr}^{++}$substitutes for $\mathrm{Ca}^{++}$in supporting release of vascular noradrenaline and in supporting sensitivity of receptors and contractility of muscles to endogenous noradrenaline but, only in part, those to exogenous noradrenaline. It has been suggested that $\mathrm{Sr}^{++}$serves as a current-carrying ion in crustacean muscle fibers (24) and in rabbit atrial myocardium (18). When $\mathrm{Ca}^{++}$in perfusion media is raised from $2.2 \mathrm{mM}$ to higher concentrations, the contractile response to noradrenaline is reduced but that to periarterial sympathetic nerve stimulation is potentiated in isolated central ear arteries of the rabbit (13). The likely explanation of this action is that there is an increase in the amount of noradrenaline released from the nerve. The present study performed on isolated aortic strips showed that the contractile response to transmural neural stimulation was not potentiated by raising either $\left[\mathrm{Ca}^{++}\right]_{0}$ or $\left[\mathrm{Sr}^{++}\right]_{0}$.

Decrease in $\left[\mathrm{Na}^{+}\right]_{0}$ caused a sustained increase in the tension: the extent of the developed tension varied inversely with $\left[\mathrm{Na}^{+}\right]_{0}$. According to Briggs and Melvin (4), a reduction in $\left[\mathrm{Na}^{+}\right]_{0}$ results in increased influx of $\mathrm{Ca}^{++}$in vascular smooth muscles. Thus, antagonism of $\mathrm{Na}^{+}$to $\mathrm{Ca}^{++}$is suggested. Although both raising $\left[\mathrm{Ca}^{++}\right]_{0}$ and lowering $\left[\mathrm{Na}^{+}\right]_{0}$ actually increased resting tension, the magnitude of contracture did not relate directly to the ratio $\left[\mathrm{Ca}^{++}\right]_{0} /\left[\mathrm{Na}^{+}\right]_{0}{ }^{2}$. This was also true in the case of the tension developed by transmural stimulation and of the sum of the tension developed by the ions and by the stimulation. As already suggested (25) no simple competition between $\mathrm{Na}^{+}$and $\mathrm{Ca}^{++}$for a specific anionic site controls the vascular tension and the contractile response of isolated rabbit aortae to noradrenaline and electrical transmural stimulation. When $\left[\mathrm{Na}^{+}\right]_{0}$ was reduced to about $64 \%$ normal, the contractile response to transmural stimulation was potentiated despite the increased resting tension. Further reduction in $\left[\mathrm{Na}^{+}\right]_{0}$ inhibited the contractile response, although the sum of the tension developed by reducing $\left[\mathrm{Na}^{+}\right]_{0}$ and by transmural stimulation was increased. Marked prolongation of the duration of contraction observed at reduced $\left[\mathrm{Na}^{+}\right]_{0}$ would suggest involvement of an inhibition of mechanisms by which noradrenaline is inactivated. It is known that the uptake of noradrenaline by sympathetic nerve terminals is inhibited by reducing $\left[\mathrm{Na}^{+}\right]_{0}(26,27)$. Cocaine, a potent inhibitor of amine uptake, 
caused an increase in the duration of contraction which greatly exceeded an increase in the magnitude of contraction.

Contractile responses to transmural stimulation and noradrenaline were potentiated by $3.4 \times 10^{-7} \mathrm{M}$ ouabain. The cardiac glycoside at $3.4 \times 10^{-6} \mathrm{M}$ caused a gradual increase in the tension and a potentiation of the response to electrical stimulation, whereas the drug in higher concentration produced an additional increase in the tension but blocked the response. These effects resemble those of lowering [ $\left.\mathrm{Na}^{+}\right]_{6}$. Activities of $\mathrm{Mg}$ ATPase in homogenates of rabbit atortae are stimulated by the addition of $\mathrm{Na}^{+}$plus $\mathrm{K}^{+}$(28). Ouabain fails to influence stimulation of the enzyme by $\mathrm{Na}^{+}$alone or $\mathrm{K}^{+}$alone but significantly inhibits the $\mathrm{Na}^{+}$plus $\mathrm{K}^{+}$activated activity (29). It is possible that ouabain permits a greater amount of noradrenaline to reach receptors by inhibiting uptake of the amine into sympathetic nerves (30). However, in the isolated rat uterus, concentrations of ouabain suffcient to cause potentiation of contractile responses to agonists fail to produce inhibition of a $\mathrm{Na}^{+}$-activated membrane ATPase (31). The present study results prove that potentiation of the contractile response to electrical stimulation by ouabain was different from that by cocaine. Cocaine markedly prolonged the induced contraction, and was suggested to result from an inhibition of the uptake of noradrenaline by sympathetic nerve terminals (32). On the other hand, ouabain increased the amplitude in parallel with the duration of contractions. The saphenous vein treated with acetylstrophanthidin showed increased reactivity to added noradrenaline, $\mathrm{Ba}^{++}$and raised $[\mathrm{K}]_{0}^{+}(33,34)$. Thus, it can be considered that the mechanism of potentiation by the glycoside involves increased fluxes of $\mathrm{Ca}^{++}$across cell membranes $(21,35)$ and increased availability of cellular $\mathrm{Ca}^{++}$. According to Bohr (36), in arterial smooth muscles, increased reactivity to calecholamines seen in the presence of desoxycorticosterone occurs by loosening of intracellular $\mathrm{Ca}^{++}$bonds, thus permitting more $\mathrm{Ca}^{++}$ to be released during excitation.

\section{SUMMARY}

Spirally-cut strips of the ascending aorta from rabbits were transmurally stimulated at frequencies of 5,20 and $100 / \mathrm{sec}$. Removal of $\mathrm{Ca}^{++}$from bathing media markedly reduced the contractile response to transmural stimulation, the reduction relating inversely to stimulation frequency. Strontium ions restored the response. Decrease in $\left[\mathrm{Na}^{+}\right]_{0}$ to 103.2 $\mathrm{mM}$ increased the resting tension of aortic strips and potentiated the contractile response to transmural stimulation. The effect of noradrenaline was slightly potentiated. Further reduction of $\left[\mathrm{Na}^{+}\right]_{n}$ caused a marked increase in the resting tension and an inhibition of contractile responses to transmural stimulation and noradrenaline. Magnitude of the contracture caused by various $\left[\mathrm{Na}^{+}\right]_{0}$ and $\left[\mathrm{Ca}^{++}\right]_{0}$ and the sum of the tension developed by variations in $\left[\mathrm{Na}^{+}\right]_{0}$ and $\left[\mathrm{Ca}^{++}\right]_{0}$ and by transmural stimulation did not relate directly to the ratio $\left.\left[\mathrm{Ca}^{++}\right]_{/ /} / \mathrm{Na}^{+}\right]_{11}{ }^{2}$. However, the dependence on reducing $\left[\mathrm{Na}^{+}\right]_{n}$ was markedly greater than that on elevating $\left[\mathrm{Ca}^{++}\right]_{\|}$. Contractile response to transmural stimulation was potentiated and the dose-response curve of noradrenaline was moved left by ouabain ( 3.4 $10^{-i}$ and $3.4 \cdot 10^{-1} \mathrm{M}$ ). Further increase in the ouabain concentration $101.7,10^{-5} \mathrm{M}$ 
caused marked increase in the resting tension but abolished the response to transmural stimulation. Repeated washing of preparations elicited partial relaxation and restoration of the response. Cocaine $\left(10^{-6}\right.$ and $\left.3 \times 10^{-6} \mathrm{M}\right)$ potentiated the response: increase in the duration of the induced contraction grcatly exceeded increase in the maximum tension developed. It seems likely that $\mathrm{Sr}^{++}$is effective in restoring release of noradrenaline from nerve terminals and responsiveness to noradrenaline in aortac deprived of $\mathrm{Ca}^{++}$, and that ouabain exerts its potentiating action at a site different from the sites of action of cocaine: the glycoside would increase cellutar $\mathrm{Ca}^{++}$available for contraction, as does lowering $\left[\mathrm{Na}^{+}\right]_{i}$.

\section{REFERENCES}

1) Robertson, P.A.: Nature 186, 316 (1960)

2) Edman, K.A.P. ANd Schild, H.O.: J. Physiol. 155, 10P (1961)

3) Durbix, R.P. AND Jfakinson, D.H.: J. Physiol. 157, 90 (1961)

4) Briggs, A.H. a.d Mflvin, S.: Am. J. Physiol. 201, 365 (1961)

5) WaUgh, W.H.: Circulation Res. 11, 264 (1962)

6) WaUgh, W.H.: Circulation Res. 11, 927 (1962)

7) Yasargil, G.M.: Helv. Physiol. Acta 18, 491 (1960)

8) Scott, J.B., Frohlici, E.D., Hardin, R.A. And Haddy, F.J.: Am. J. Physiol. 201, 1095 (1961)

9) Feinblirg, H., Boyd, E. And Katz, L.N.: Am. J. Physiol. 202, 643 (1962)

10) Briggs, A.H.: Am. J. Physiol. 203, 849 (1962)

11) Borr, D.F.: Scionce 139, 597 (1963)

12) Su, C. And Bevan, J.A.: J. Pharmac, exp. Ther, 172, 62 (1970)

13) Farmer, J.B. and Campbell, I.K.: Br. J. Pharmac. Chemother. 29, 319 (1967)

14) Heilibrunn, L.V. and Wiercinski, F.J.: J. Cellular Comp. Physiol. 29, 15 (1947)

15) Frank, G.B.: J. Physiol. 163, 254 (1962)

16) Frank, G.B.: J. Pharmac, exp. Ther. 139, 261 (1963)

17) Hudgins, P.M.: J. Pharmac. exp. Ther. 170, 303 (1969)

18) TODA, N.: Circulation Res. 28, 545 (1971)

19) Lüttgau, H.C. and Niedergerke, R.: J. Physiol. 143, 486 (1958)

20) Horst, W.D., Kopty, I.J. AND Ramey, E.R.: Am. J. Physiol. 215, 817 (1968)

21) Lüllmann, H. and Hold.and, W.: J. Pharmac. exp. Ther. 137, 186 (1962)

22) Govier, W.C. and Holland, W.C.: Am. J. Physiol, 207, 195 (1964)

23) TODA, N., Usui, H. and Mort, J.: Jap. J. Pharmac. 21, 59 (1972)

24) Fatt, P. and Ginsborg, B.L.: J. Physiol. 142, 516 (1958)

25) Nash, C.W., Luchka, E.V. And Jhamandas, K.H.: Can. J. Physiol. Pharmac. 44, 147 (1966)

26) Iversen, L.L. And Kravitz, E.A.: Mol. Pharmac. 2, 360 (1966)

27) Bogdanski, D.F. ANd Brodil, B.B.: Life Sci. 5, 1563 (1966)

28) Bonting, S.L., Simon, K.A. and Hawkins, N.M.: Arch. Biochem. Biophys. 95, 416 (1961)

29) Wolowyk, M.W., Kidwai, A.M. and Daniel, E.E.: Can. J. Biochem. 49, 376 (1971)

30) Dengler, H.J., Spiegel, H.F. A.nd Titus, E.O.: Science 133, 1072 (1961)

31) Danirl, E.E., Massingilam, R. and Nasmytit, P.A.: Br. J. Pharmac, Chemother. 34, 231P (1968)

32) TODA, N.: J. Pharmac. exp. Ther. 179, 198 (1971)

33) Brfader, D., Vanhoutte, P.M. And ShePherd, J.T.: Circulation Res. 25, 597 (1969)

34) Brevder, D., Strong, C.G. ANd Shepherd, J.T.: Circulation Res. 26, 647 (1970)

35) Sekul, A.A. and Holland, W.C.: Am. J. Physiol. 199, 457 (1960)

36) BoHr, D.F.: Can. Med. Ass. 90, 174 (1964) 